\title{
Idaho National Laboratory Vadose Zone Research Park Geohydrological Monitoring Results
}

Kristine Baker

January 2006

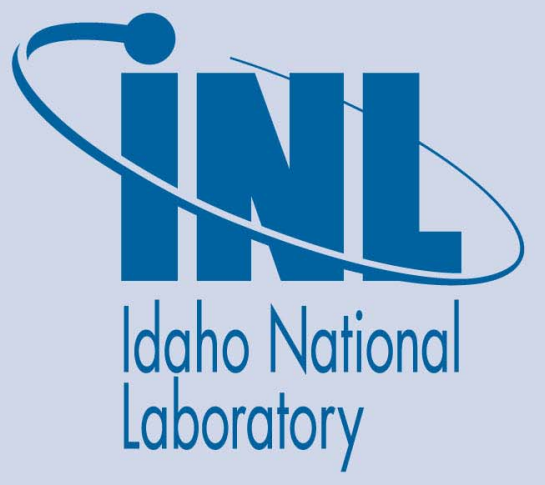

The INL is a U.S. Department of Energy National Laboratory operated by Battelle Energy Alliance 
INL/EXT-05-01044

\section{Idaho National Laboratory Vadose Zone Research Park Geohydrological Monitoring Results}

Kristine Baker

January 2006

Idaho National Laboratory

Idaho Falls, Idaho 83415

Prepared for the

U.S. Department of Energy

Through the INL LDRD Program

Under DOE Idaho Operations Office

Contract DE-AC07-05ID14517 


\begin{abstract}
Vadose zone lithology, hydrological characterization of interbed sediments, and hydrological data from subsurface monitoring of Idaho Nuclear Technology and Engineering Center wastewater infiltration are presented. Threedimensional subsurface lithology of the vadose zone beneath the Vadose Zone Research Park is represented in a 2-dimensional (2-D) diagram showing interpolated lithology between monitoring wells. Laboratory-measured values for saturated hydraulic conductivity and porosity are given for three major interbeds, denoted as the B-BC interbed ( 20 to $35 \mathrm{~m}$ bls), the C-D interbed ( 40 to $45 \mathrm{~m}$ bls), and the DE-1-2 interbed (55 to $65 \mathrm{~m}$ bls), along with an overall physical description of the sediments and geologic depositional environments. Preoperational pore water pressure conditions are presented to show the presence and location of perched water zones before pond discharge at the New Percolation Ponds. Subsurface infiltration conditions during initial high-volume discharge are presented to show water arrival times and arrival sequences.

Steady-state conditions are then presented to show formation and locations of perched water zones and recharge sources after several months of discharge to the New Percolation Ponds.
\end{abstract}




\section{CONTENTS}

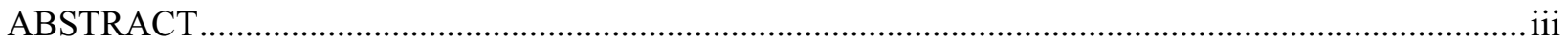

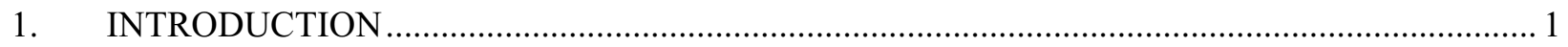

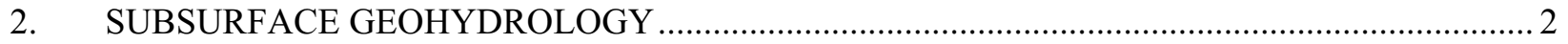

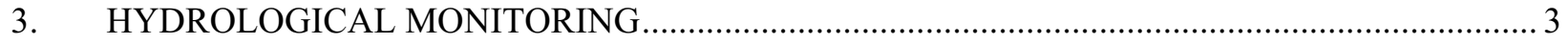

3.1 Pre-operation Subsurface Conditions ….................................................................... 3

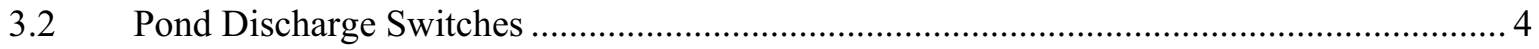

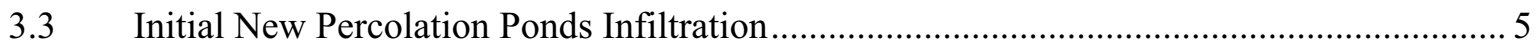

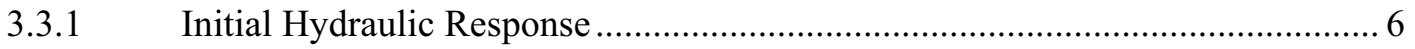

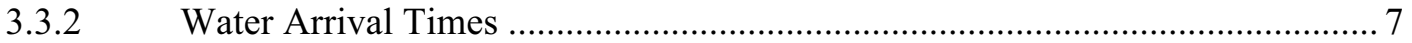

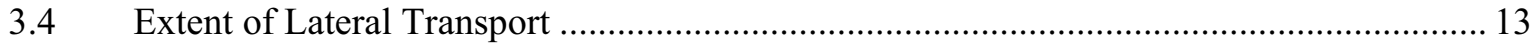

3.4.1 Steady State Perched Water Conditions........................................................ 15

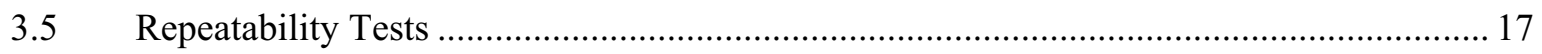

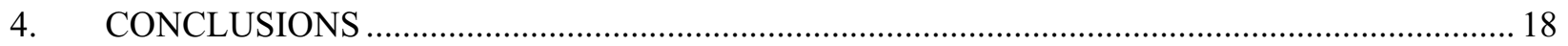

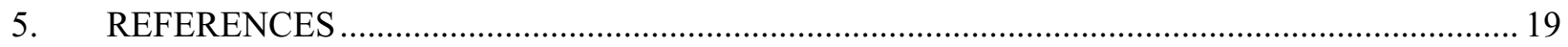

\section{FIGURES}

1. Aerial photo of the INL showing the location of the new percolation ponds and VZRP relative to INTEC and the Big Lost River.

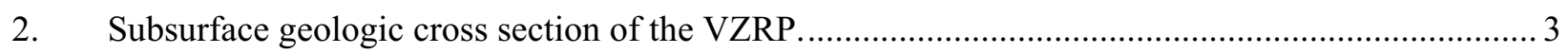

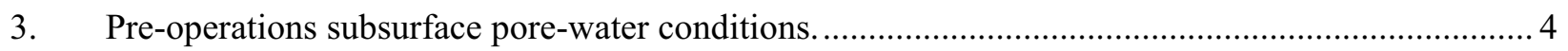

4. Map of the VZRP showing the location of aquifer wells and core holes ..................................... 5

5. Well ICPP-SCI-V-204 tensiometer response to initial water arrival and changes in discharge location for August through October 2002 ........................................................................... 6

6. Well ICPP-SCI-V-205 tensiometer responses to initial water arrival and changes in discharge location for August through October 2002 ........................................................................

7. Well ICPP-SCI-V-198 tensiometer responses to initial water arrival and changes in discharge location for August through October 2002 .. 8 
8. Well ICPP-SCI-V-215 tensiometer responses to initial water arrival and changes in discharge location for August through October 2002

9. Water arrival sequence beneath the VZRP percolation ponds for Borehole ICPP-SCI-V-204, based on tensiometer data collected from July 1, 2002 through October 31, 2002.

10. Water arrival sequence beneath the VZRP percolation ponds for Borehole ICPP-SCI-V-215, based on tensiometer data collected from July 1, 2002 through October 31, 2002

11. Grouped lithology initial water arrival dates as a function of lateral distance from the center of the berm between the ponds for the alluvium/basalt interface, the B-BC interbed, and the C-D interbed for Wells ICPP-SCI-V-198, ICPP-SCI-V-204, ICPP-SCI-V-205, and ICPP-SCI-V-215.

12. Well ICPP-SCI-V-189 advanced tensiometer readings at $31 \mathrm{~m}$ bls

13. Chloride concentrations in pore water and perched water at approximately $30 \mathrm{~m}$ depth north of the Big Lost River

14. Hydraulic conditions after one month of continuous discharge to the south cell at the New Percolation Ponds

15. Perched water thickness measured in vadose zone monitoring wells at the VZRP in March 2003.17

16. Example of hydraulic response to changes in discharge location during controlled effluent discharge switches between the north and south cells of the percolation ponds at the VZRP from October 2004 through December 2004.

\section{TABLES}

1. Summary of mean values for VZRP interbed sediment physical and hydrological properties .......... 2

2. Velocity estimates for water flow based on hypotenuse distance from the center of the berm between percolation ponds to the sensor's depth below land surface 


\section{Idaho National Laboratory Vadose Zone Research Park Geohydrological Monitoring Results}

\section{INTRODUCTION}

The Vadose Zone Research Park (VZRP) was established in 2001 to study the subsurface hydrology and geochemistry of a relatively undisturbed and uncontaminated area at the Idaho National Laboratory (INL). The vision for this facility was that monitoring the response of the vadose zone to hydraulic and chemical inputs over time would allow scientists to develop theories of how water and contaminants move through the vadose zone. The VZRP monitors a composite section of the vadose zone, including alluvium, basalt, and sedimentary interbeds. Data from this research is used to evaluate the impacts of current INL operations, support new facilities and programs at INL, and provide the basis for remedial actions decisions for past releases of contaminants to the environment. The VZRP includes the Idaho Nuclear Technology and Engineering Center (INTEC) percolation ponds (a continuous recharge source) and the Big Lost River (an intermittent recharge source). Monitoring wells and instrumented boreholes were installed around the perimeter of the ponds, on both sides of the Big Lost River, and along a transect between the two (Figure 1).

This report presents and discusses data from July 2002 through September 2005.

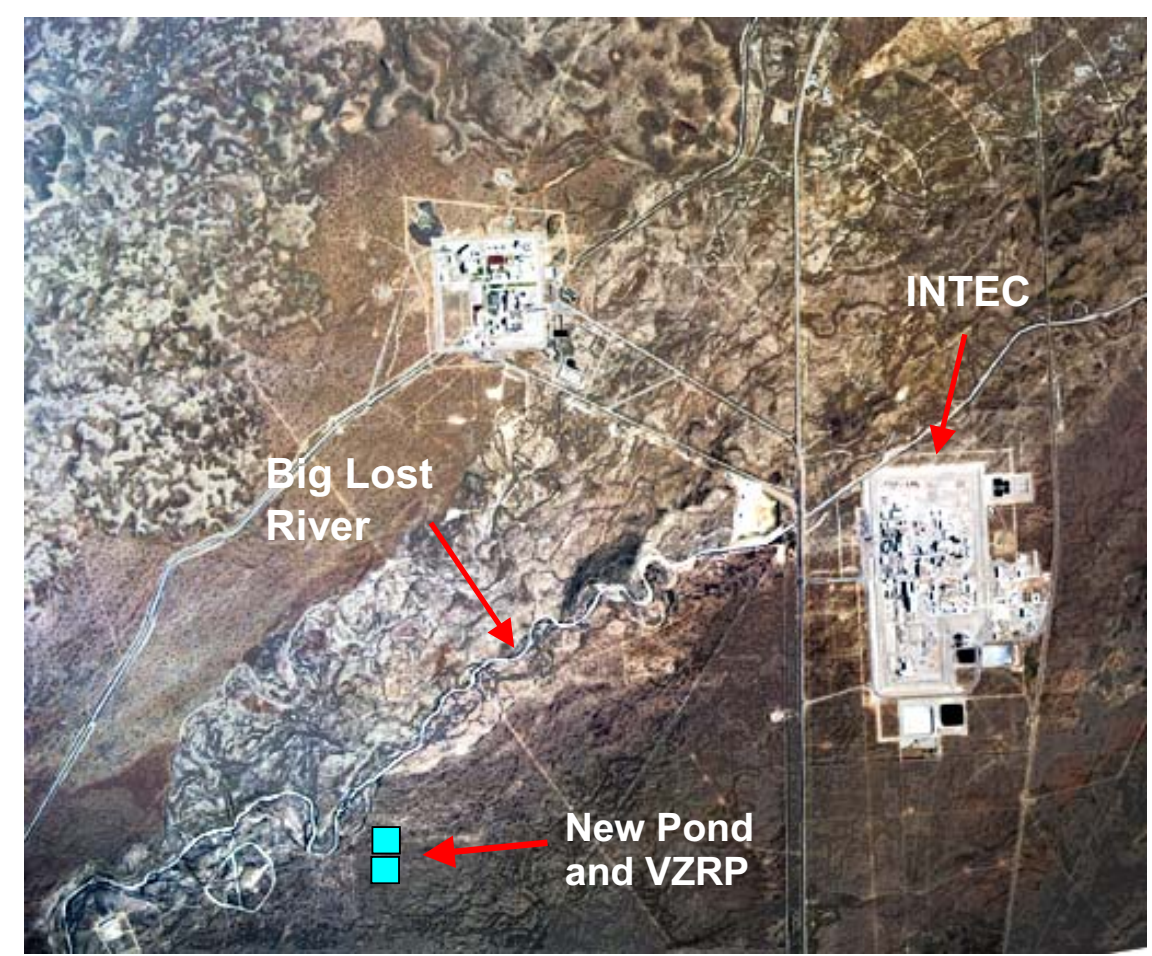

Figure 1. Aerial photo of the INL showing the location of the new percolation ponds and VZRP relative to INTEC and the Big Lost River. 


\section{SUBSURFACE GEOHYDROLOGY}

A geologic model was constructed from a compilation of geologic core logs recorded during drilling, borehole geophysics and video logs, and geologic characterization from intact core collected during well installations. The model identifies 41 lava flows from analysis of core collected from geophysics Well ICPP-SCI-V-213 and boreholes ICPP-SCI-V-214 and ICPP-SCI-V-215 (Champion and Herman 2003). These flows are grouped into nine distinct basalt eruptive events based on paleomagnetic inclination measurements (Figure 2). Three major interbeds were identified at approximately 20, 40, and 55 meters below land surface ( $\mathrm{m}$ bls), denoted as the B-BC, C-D, and the DE-1-2 interbeds, respectively. The B-BC interbed ranges in thickness from 0.6 to $8.5 \mathrm{~m}$, pinching out toward the north end of the ponds, then reappearing near the river. The B-BC interbed is present in all 25 boreholes drilled to its depth or deeper. The C-D interbed ranges from 0.6 to $10 \mathrm{~m}$ in thickness and is present in 7 of the 18 holes drilled to its depth. The DE-1-2 interbed ranges in thickness from 0.3 to $14 \mathrm{~m}$ and was encountered in 9 of the 10 boreholes drilled to its depth. The B-BC interbed is laterally extensive to at least $900 \mathrm{~m}$ within the VZRP between the Big Lost River and the New Percolation Ponds area. Because most of the boreholes were drilled to the DE-1-2 interbed or less, it is difficult to make inferences about the lateral continuity of the C-D and DE-1-2 interbeds.

The interbed sediment for all three major interbeds was classified as a silt loam using the U.S. Department of Agriculture classification scheme for percent sands, silts, and clays (Winfield 2003). The mean particle size for all interbed intervals ranges from 0.0034 to $0.1992 \mathrm{~mm}$. The B-BC interbed is vertically more uniform and is finer than the other two interbeds. The mean grain size in the B-BC interbed ranges from 0.0034 to $0.0160 \mathrm{~mm}$. The C-D interbed coarsens upward both locally and over a distance of $200 \mathrm{~m}$. The greatest spread in particle size is near the top of the C-D interbed, with mean grain sizes ranging from 0.0038 to $0.1715 \mathrm{~mm}$. The DE-1-2 interbed shows the most textural variation, with the mean diameter ranging from 0.0081 to $0.1992 \mathrm{~mm}$ (Table 1).

The range of saturated hydraulic conductivity $\left(\mathrm{K}_{\mathrm{sat}}\right)$, based on laboratory measurements of core samples, for the three major interbeds was from $1.66 \times 10^{-7} \mathrm{~cm} \mathrm{~s}^{-1}$ to $1.42 \times 10^{-3} \mathrm{~cm}^{-1}$. The B-BC interbed samples had values in the low to middle range of the spectrum with a mean value of $1.53 \times 10^{-6} \mathrm{~cm} \mathrm{~s}^{-1}$. Mean porosity of the B-BC interbed was 0.468 . Measured $\mathrm{K}_{\text {sat }}$ values for the C-D interbed decreased with depth, consistent with the downward fining of particle sizes, with a mean hydraulic conductivity of $6.67 \times 10^{-5} \mathrm{~cm} \mathrm{~s}^{-1}$ and a mean porosity of 0.496 . For the DE-1-2 interbed, $\mathrm{K}_{\text {sat }}$ generally increased with depth. The mean hydraulic conductivity for the DE-1-2 interbed was $3.64 \times 10^{-4} \mathrm{~cm} \mathrm{~s}^{-1}$ with a mean porosity of 0.514 .

Table 1. Summary of mean values for VZRP interbed sediment physical and hydrological properties.

\begin{tabular}{|c|c|c|c|c|}
\hline $\begin{array}{l}\text { Interbed } \\
\text { Identifier }\end{array}$ & $\begin{array}{c}\text { Approximate } \\
\text { Depth }(\mathrm{m})\end{array}$ & $\begin{array}{c}\text { Saturated } \\
\text { Hydraulic } \\
\text { Conductivity } \\
\left(\mathrm{cm} \mathrm{s}^{-1}\right)\end{array}$ & $\begin{array}{l}\text { Porosity } \\
(\mathrm{mL} / \mathrm{mL})\end{array}$ & $\begin{array}{c}\text { Particle Size } \\
\text { Diameter Range } \\
(\mathrm{mm})\end{array}$ \\
\hline $\mathrm{B}-\mathrm{BC}$ & 20 & $1.53 \times 10^{-6}$ & 0.468 & 0.0034 to 0.0160 \\
\hline C-D & 40 & $6.67 \times 10^{-5}$ & 0.496 & 0.0038 to 0.1715 \\
\hline DE-1-2 & 55 & $3.64 \times 10^{-4}$ & 0.514 & 0.0081 to 0.1992 \\
\hline
\end{tabular}




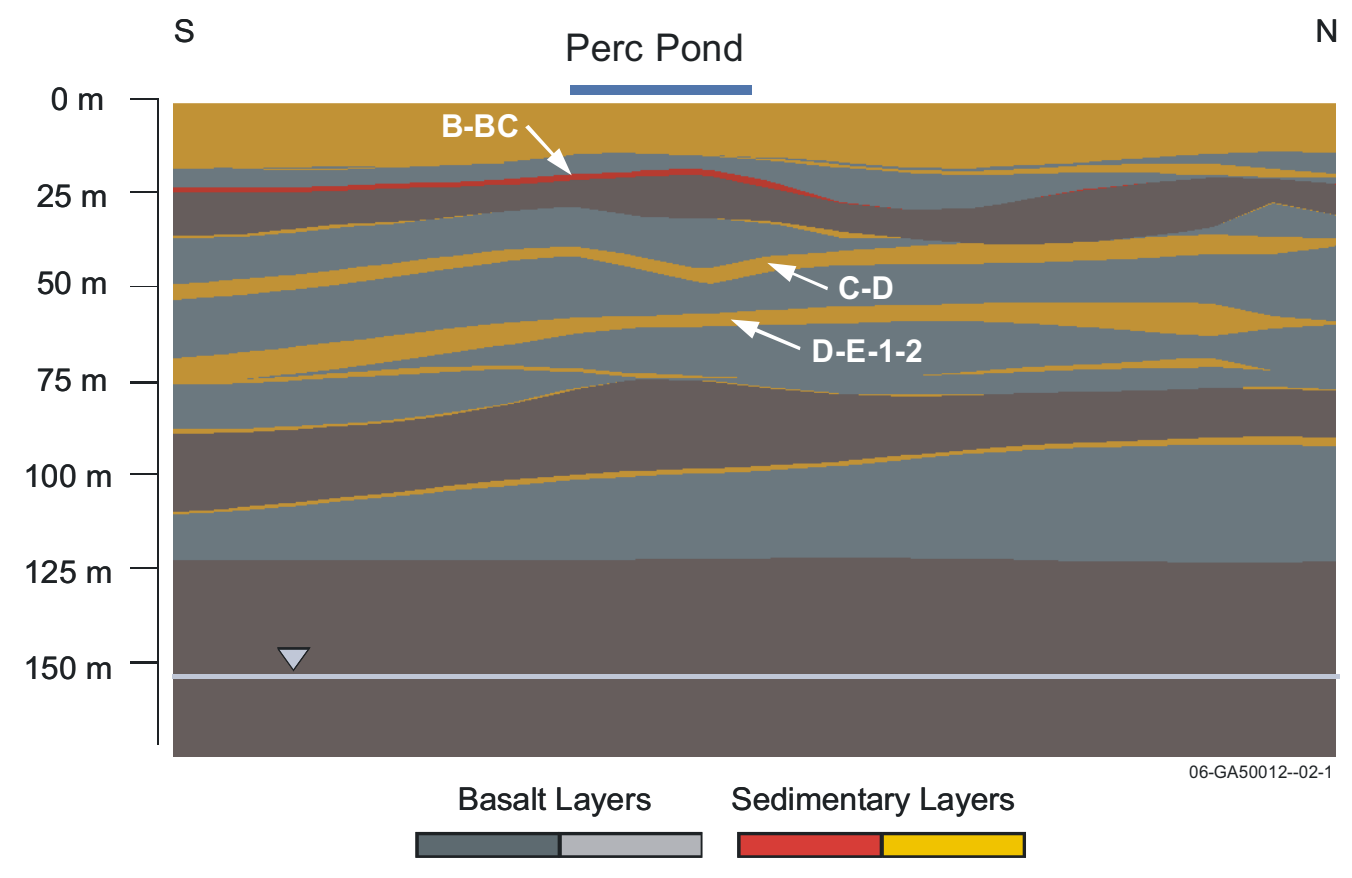

Figure 2. Subsurface geologic cross section of the VZRP. The cross section is a north-south slice ( $\sim 1 \mathrm{~km}$ long) through the center of the ponds north to the Big Lost river, viewed from the east. The water table, at a depth of $153 \mathrm{~m}$, is shown by the horizontal blue line and triangle.

\section{HYDROLOGICAL MONITORING}

\subsection{Pre-operation Subsurface Conditions}

Pre-operation laboratory measurements of the moisture content of cores collected during well and instrument installation indicate that interbed deposits were relatively dry $(<20 \%$ volumetric moisture content). An exception was core collected from the C-D interbed (approximately $45 \mathrm{~m}$ bls) in Wells ICPP-SCI-V-213 and ICPP-SCI-V-214; these measurements showed volumetric moisture of 40 and 51\%, respectively. Pre-operational in situ measurements of moisture content and matric potential support these findings, showing unsaturated conditions at depths ranging from 13 to $147 \mathrm{~m}$ bls. An exception was the C-D interbed, which showed saturated conditions in Wells ICPP-SCI-V-204 and ICPP-SCI-V-198, and basalt at approximately the same depths (45 to $50 \mathrm{~m}$ bls) in ICPP-SCI-V-214, ICPP-SCI-V-195, and ICPP-SCI-V-189. Saturated conditions were also observed in Well ICPP-SCI-V-215 at a depth of $87 \mathrm{~m}$ bls (Figure 3).

The saturated perched water zone at $45 \mathrm{~m}$ bls (Figure 3) increases in thickness in a southern direction, away from the river toward the New Percolation Ponds. The perched water is only a few $\mathrm{cm}$ thick near the river and reaches nearly a meter in thickness near the ponds. The increase toward the ponds may be related to the south dipping lithofacies that slopes toward a depression directly beneath the ponds (Figure 2). The perched water zone identified southeast of the percolation ponds within a thick basalt layer at a depth of almost $90 \mathrm{~m}$ bls also had a thickness of $1 \mathrm{~m}$ before operations began at the New Percolation Ponds. The extent of the perched zone cannot be identified at this time since no additional monitoring locations are completed at this depth south or southeast of the ponds. 


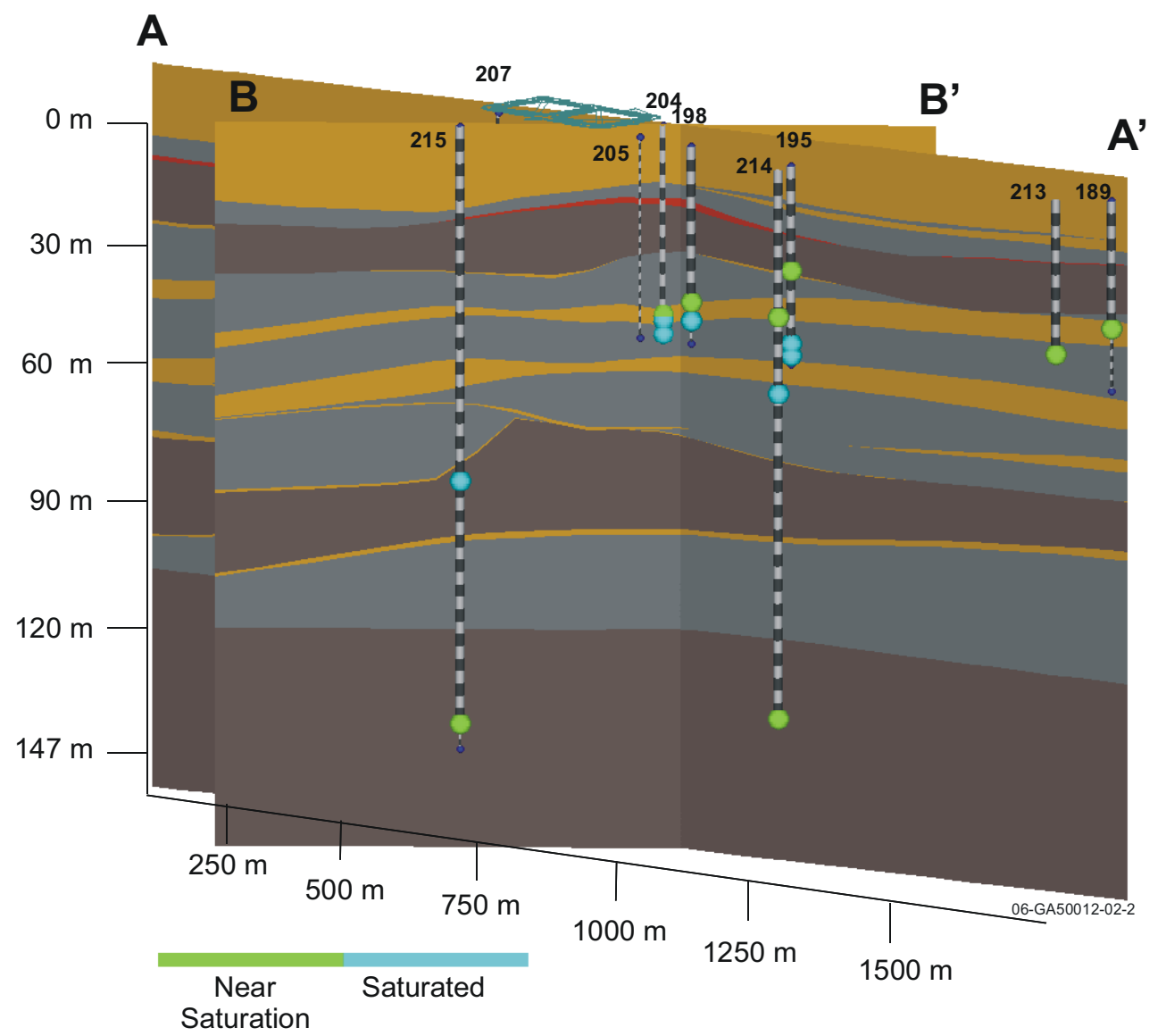

Figure 3. Pre-operations subsurface pore-water conditions. The locations of Cross Sections A-A' and B-B' are displayed on the map in Figure 4. Blue bulbs represent perched water regions, green bulbs represent near saturation ( $\sim 0 \mathrm{~cm}$ hydraulic head). Borehole ICPP-SCI-V-207 is not visible from this angle; however, the subsurface is dry ( $<0 \mathrm{~cm}$ hydraulic head) within the monitoring region.

The only known source of recharge to the vadose zone prior to operations at the New Percolation Ponds was natural precipitation and infiltration from the Big Lost River. Natural precipitation at the VZRP - $22 \mathrm{~cm}$ per year - is not sufficient to form extensive perched water zones at depth. Although the Big Lost River has been identified as a source of local recharge to the C-D interbed (Nimmo et al. 2002), the river is historically intermittent, depending on upstream irrigation in the Big Lost River basin. The last recorded extended period of flow in the channel adjacent to the VZRP was in May 2000. Therefore, it appears that perched water does not drain rapidly in complex, heterogeneous vadose zones after recharge ceases.

\subsection{Pond Discharge Switches}

The New Percolation Ponds were constructed at the INL in 2000 as part of a remedial action to prevent the migration of contaminants in the vadose zone under the INTEC to the aquifer. The previous industrial wastewater pond was located immediately adjacent to the INTEC facility, and received between 3,785 and $5,700 \mathrm{~m}^{3}$ day $^{-1}$. The new ponds were constructed $3 \mathrm{~km}$ southwest of the INTEC facility to permit the vadose zone under INTEC to drain, thus removing a significant driving force for migration of 


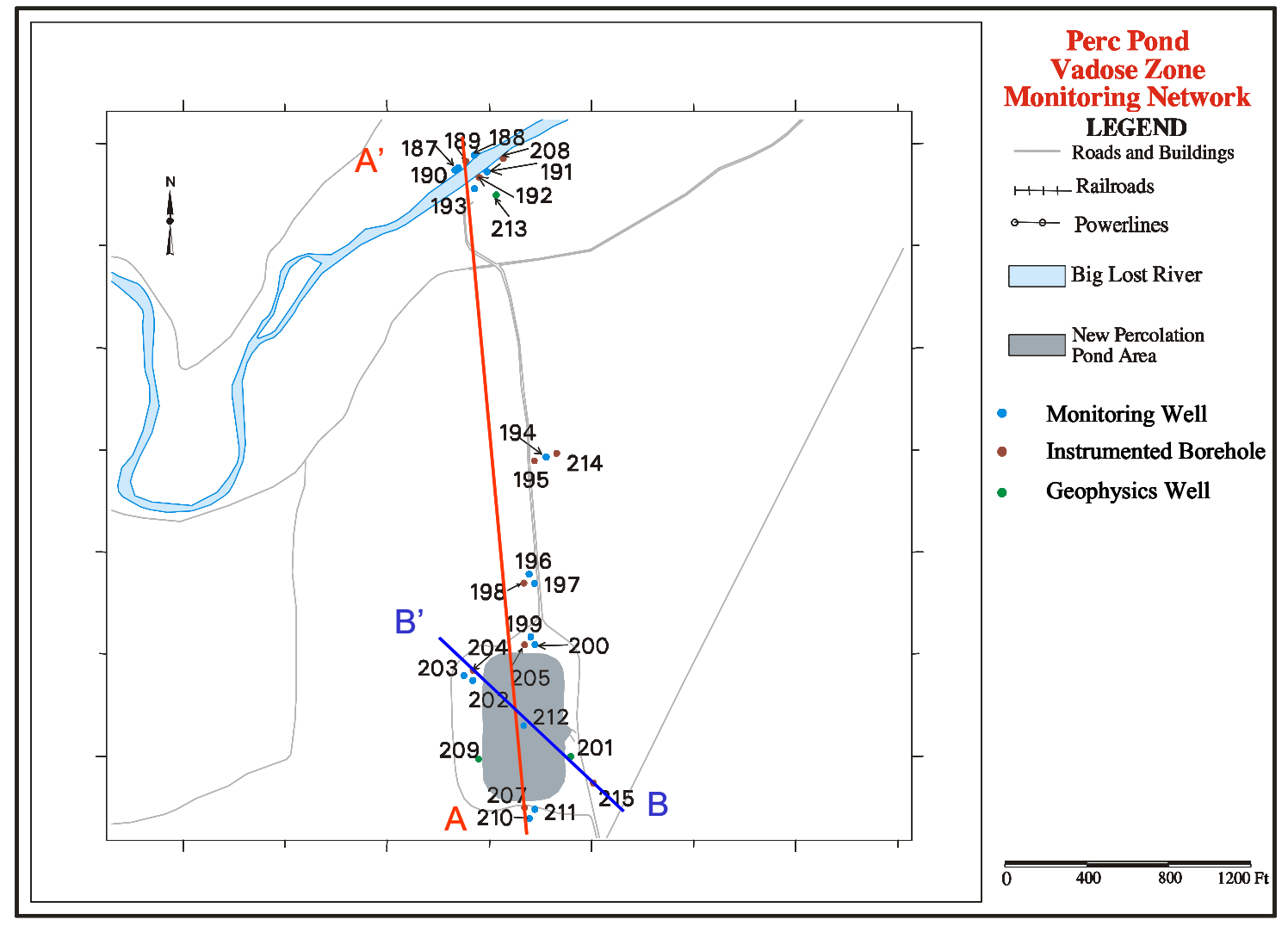

Figure 4. Map of the VZRP showing the location of aquifer wells and core holes. Cross Sections A-A' and B-B' are slices through the vadose zone used to visualize subsurface hydrological conditions.

contaminants through the vadose zone. The ponds consist of two square cells-a south cell and a north cell-each $93 \mathrm{~m}$ (305 ft) on a side. Approximately on an annual basis, flow is switched between cells so that algae and plants in the pond, which slow infiltration, die off and hydraulic conductivity is reestablished.

Initial continuous discharge to the New Percolation Ponds began August 26, 2002. Flow was intermittently switched back and forth between the ponds from June 2002 through October 5, 2002 while testing pumps. Then effluent water was continuously discharged to the south cell of the ponds at a flux rate of approximately $5678 \mathrm{~m}^{3}$ day $^{-1}$. Since August 2002, pond switches have occurred periodically either to accommodate research activities or to prevent over-filling the ponds during periods of slow infiltration.

\subsection{Initial New Percolation Ponds Infiltration}

High-volume discharge $\left(>4000 \mathrm{~m}^{3} \mathrm{day}^{-1}\right)$ to the south cell began August 26, 2002 and continued through September 20,2002. Discharge was switched from the south cell to the north cell on September 21, 2002, then switched back to the south cell October 5, 2002. During this time period, water pressure, water content, and water level data show rapid response to infiltration and changes in discharge locations (switches between the north and south cells of the ponds). 


\subsubsection{Initial Hydraulic Response}

Hydraulic response to initial infiltration beneath the New Percolation Ponds was recorded using advanced tensiometers, time domain reflectometry (TDR) probes, electrical resistivity tomography (ERT) electrodes, and water-level sensors. Water-level sensors require a minimum depth of standing water in the wells, resulting in a delayed response and, therefore, are not ideal for monitoring initial water arrival times. TDR and ERT arrays are not as extensive throughout the VZRP as the advanced tensiometer packages and, therefore, the data cannot be used to monitor water arrival as comprehensively as the tensiometer data. The advanced tensiometers respond very rapidly to minor changes in matric and hydraulic potentials (negative and positive pressures, respectively) and are not sensitive to minor changes in pore water chemistry, reminiscent of the TDR and ERT arrays. Therefore, tensiometer data were selected to represent initial New Percolation Ponds infiltration water arrival times.

Water pressure data collected from instrumented boreholes around the perimeter of the ponds show rapid response to infiltration once high-volume discharge began in August 2002. Unfortunately, the data logger battery at station 207 failed during September 2002 and data were not recorded for Well ICPP-SCI-V-207 until October 2002. Sensors in Wells ICPP-SCI-V-204, ICPP-SCI-V-205, and ICPP-SCI-V-215 began responding to water infiltration at the end of August 2002. Most of the shallow sensors in Wells ICPP-SCI-V-204 and ICPP-SCI-V-205 responded very quickly to initial infiltration and changes in discharge location that occurred from August 27 through October 4, 2002 (Figures 5 and 6, respectively). A delayed rapid response to infiltration was observed in Well ICPP-SCI-V-198 (Figure 7), which also shows response to changes in discharge location. Sensors in Well ICPP-SCI-V-215 show rapid infiltration near the C-D interbed (Figure 8, 215-45m-I and 215-43m-B) and slow infiltration near the

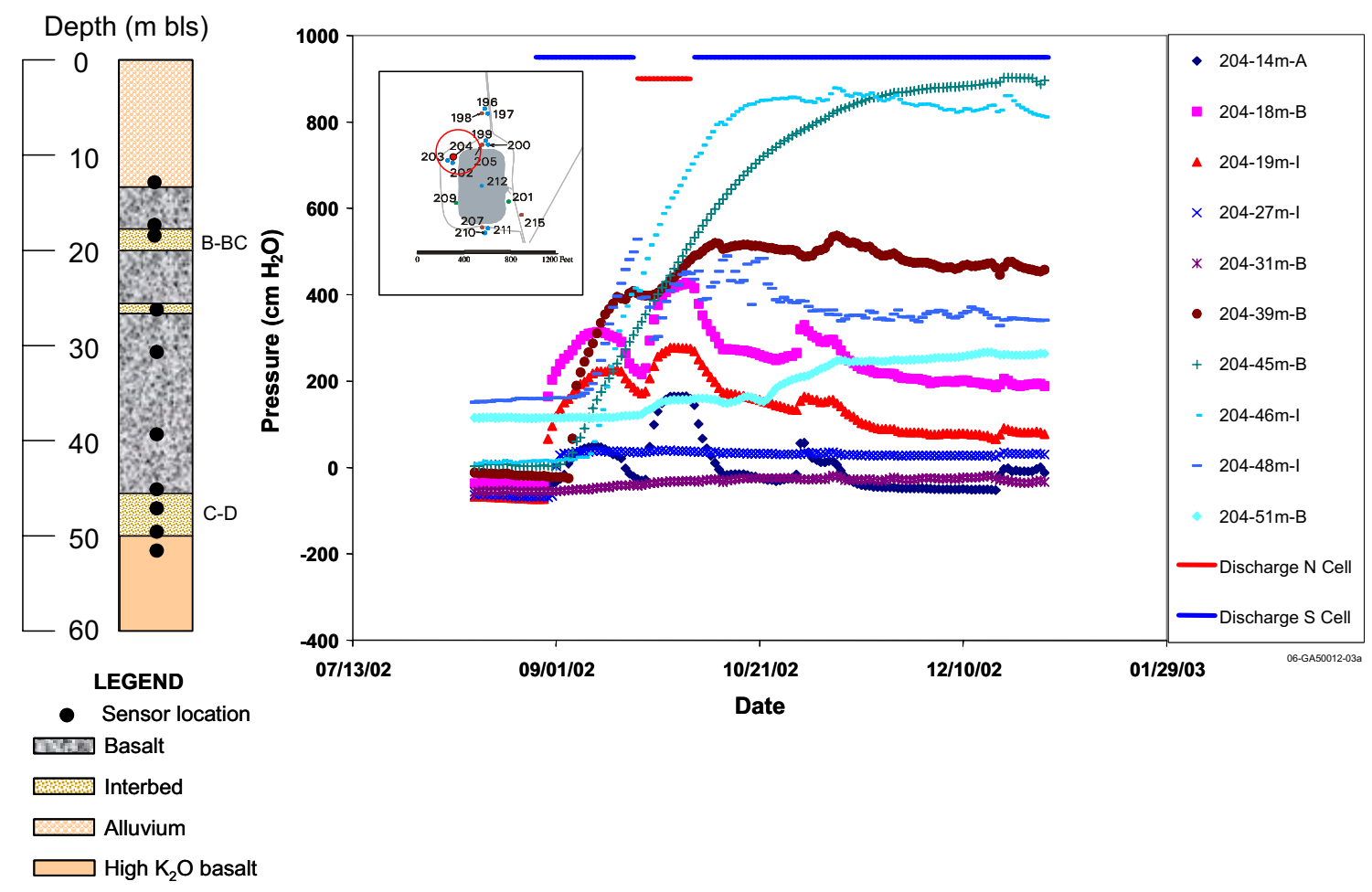

Figure 5. Well ICPP-SCI-V-204 tensiometer response to initial water arrival and changes in discharge location for August through October 2002. Pressure spikes in early November reflect a rapid increase in discharge volume, which lasted about 4 days. Tensiometers in this well were pulled for calibration on December 19, 2002, also showing a minor spike in pressure. A = alluvium, B = basalt, I = interbed. 


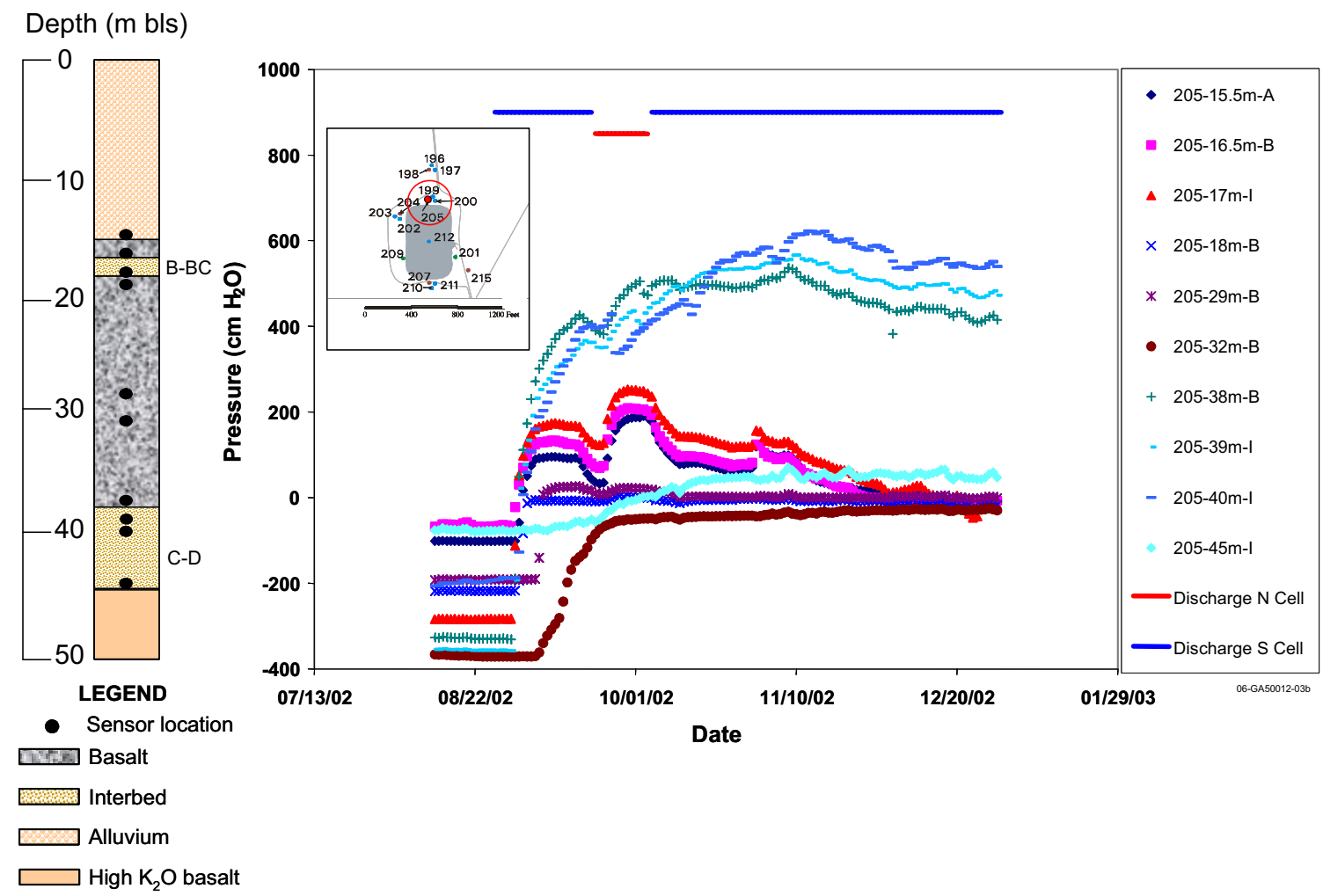

Figure 6. Well ICPP-SCI-V-205 tensiometer responses to initial water arrival and changes in discharge location for August through October 2002. Pressure spikes in early November reflect a rapid increase in discharge volume, which lasted about 4 days. $\mathrm{A}=$ alluvium, $\mathrm{B}=$ basalt, $\mathrm{I}=$ interbed.

DE-1-2 interbed (Figure 8, 215-58m-I). The only sensors that appeared to respond to changes in discharge location in Well ICPP-SCI-V-215 are located near the interface of the C-D interbed where water pressures increased at $43 \mathrm{~m}$ and decreased at $45 \mathrm{~m}$. This dichotomy in hydraulic response within a 2-m vertical region suggests the presence of separate perched water zones with unique transport pathways.

\subsubsection{Water Arrival Times}

Water transport times for each well receiving recharge, calculated from initial arrival and hypotenuse distance from the ponds, ranged from 3 to $35 \mathrm{~m}_{\text {day }}{ }^{-1}$ (Table 2). Nonsequential vertical transport was observed during initial water arrival to vadose zone sensors in four of the five observation wells that received recharge from the ponds during initial infiltration (Figure 9). The only well exhibiting sequential water arrival was Well ICPP-SCI-V-215 (Figure 10). Nonsequential lateral transport was also observed within similar lithofacies (Figure 11). Water arrived at the alluvium/basalt interface at Well ICPP-SCI-V-215 (138 $\mathrm{m}$ from the ponds and $24 \mathrm{~m}$ bls) a couple days before arriving at Wells ICPP-SCI-V-204 and ICPP-SCI-V-205 (both $120 \mathrm{~m}$ from the ponds and approx $15 \mathrm{~m}$ bls). Faster transport to Well ICPP-SCI-V-215 may be related to the depression under the ponds on the southern end at the alluvium/basalt interface (Figure 2). Water arrived at the C-D interbed in Well ICPP-SCI-V-198 at approximately the same time (within a day) as Wells ICPP-SCI-V-204, ICPP-SCI-V-205, and ICPP-SCI-V-215, all of which are nearly $100 \mathrm{~m}$ closer to the ponds than ICPP-SCI-V-198. This suggests that a fast pathway may exist from the ponds to the C-D interbed in Well ICPP-SCI-V-198. 


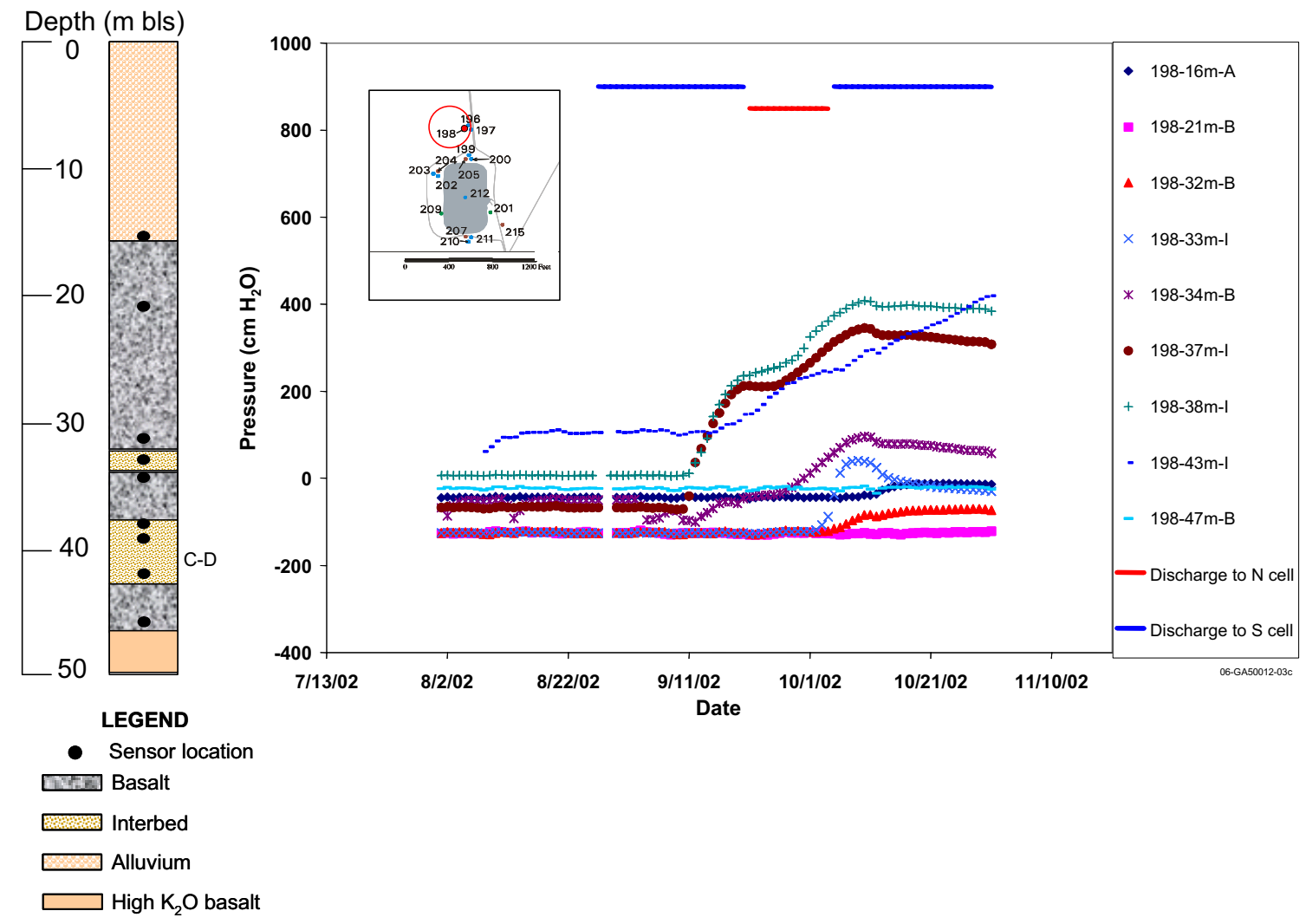

Figure 7. Well ICPP-SCI-V-198 tensiometer responses to initial water arrival and changes in discharge location for August through October 2002. A = alluvium, B = basalt, I = interbed. 


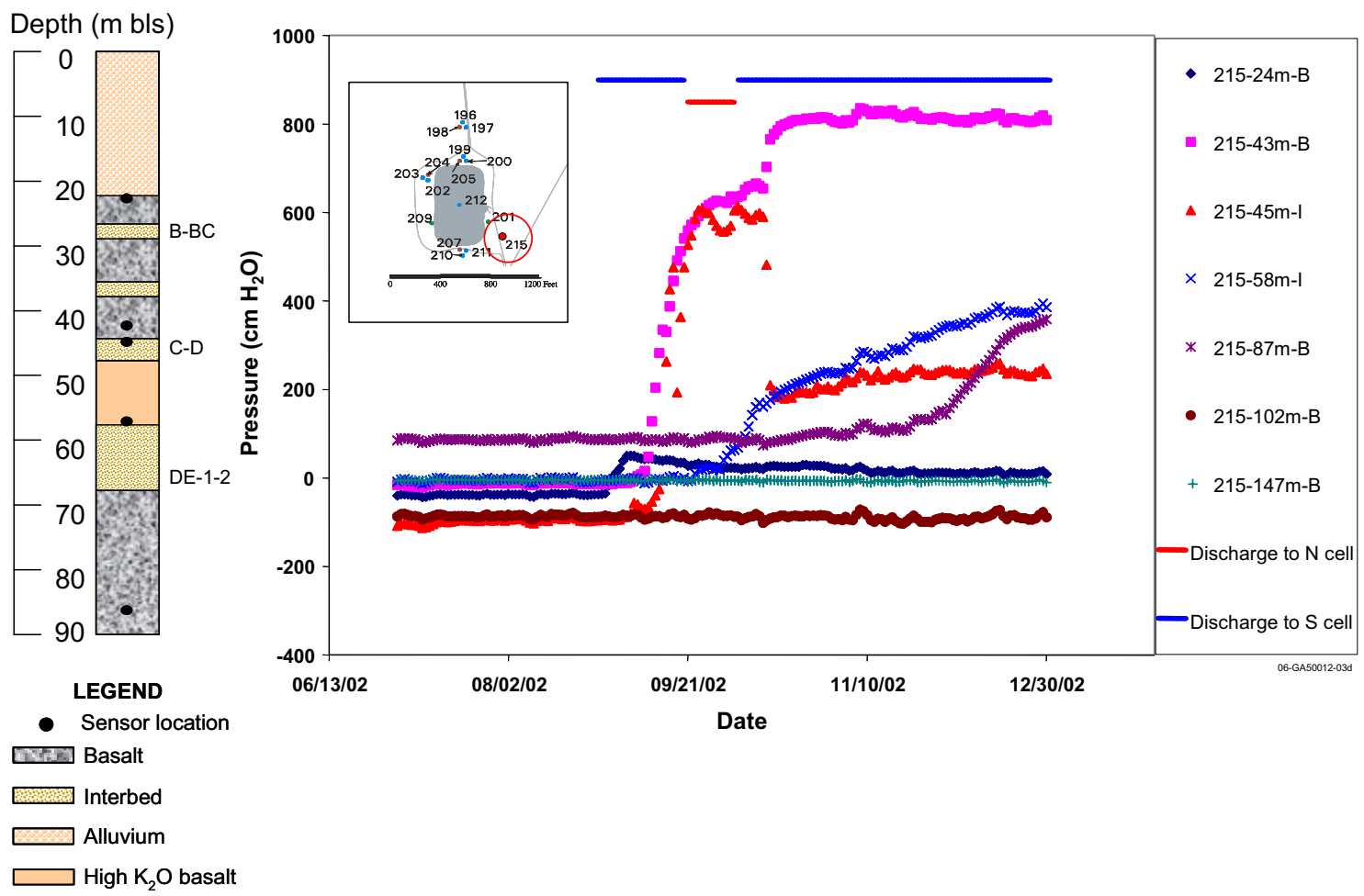

Figure 8. Well ICPP-SCI-V-215 tensiometer responses to initial water arrival and changes in discharge location for August through October 2002. Pressure spikes in early November reflect a rapid increase in discharge volume, which lasted about 4 days. $\mathrm{A}=$ alluvium, $\mathrm{B}=$ basalt, $\mathrm{I}=$ interbed. 
Table 2. Velocity estimates for water flow based on hypotenuse distance from the center of the berm between percolation ponds to the sensor's depth below land surface.

\begin{tabular}{|c|c|c|c|c|c|c|c|c|}
\hline Sensor ID & $\begin{array}{r}\text { Depth } \\
\text { bls(m) }\end{array}$ & $\begin{array}{c}\text { Initial } \\
\text { Pressure } \\
\text { Head } \\
(\mathrm{cm})\end{array}$ & $\begin{array}{c}\text { Initial } \\
\text { Discharge } \\
\text { Date }\end{array}$ & $\begin{array}{c}\text { Date of } \\
\text { First } \\
\text { Response }\end{array}$ & $\begin{array}{c}\text { Travel } \\
\text { Time } \\
\text { (days) }\end{array}$ & $\begin{array}{l}\text { Radial } \\
\text { Distance } \\
\text { from } \\
\text { Center of } \\
\text { Berm } \\
\text { (m) }\end{array}$ & $\begin{array}{l}\text { Hypotenuse } \\
\text { Distance } \\
(\mathrm{m})\end{array}$ & $\begin{array}{c}\text { Flow } \\
\text { Velocity } \\
\text { (m/day) }\end{array}$ \\
\hline 198-AT-106 & 32 & -115 & $8 / 26 / 2002$ & $10 / 6 / 2002$ & 41 & 215 & 217 & 5 \\
\hline 198-AT-109 & 33 & -121 & $8 / 26 / 2002$ & $10 / 7 / 2002$ & 42 & 215 & 218 & 5 \\
\hline 198-AT-113 & 34 & -100 & $8 / 26 / 2002$ & $9 / 15 / 2002$ & 20 & 215 & 218 & 11 \\
\hline 198-AT-121 & 37 & -70 & $8 / 26 / 2002$ & $9 / 10 / 2002$ & 15 & 215 & 218 & 15 \\
\hline 198-AT-125 & 38 & 7 & $8 / 26 / 2002$ & $9 / 10 / 2002$ & 15 & 215 & 218 & 14 \\
\hline 198-AT-140 & 43 & 103 & $8 / 26 / 2002$ & $9 / 15 / 2002$ & 20 & 215 & 219 & 11 \\
\hline 204-AT-045 & 14 & -40 & $8 / 26 / 2002$ & $8 / 31 / 2002$ & 5 & 120 & 121 & 24 \\
\hline 204-AT-058 & 18 & -38 & $8 / 26 / 2002$ & $8 / 30 / 2002$ & 5 & 120 & 122 & 25 \\
\hline 204-AT-063 & 19 & -70 & $8 / 26 / 2002$ & $8 / 30 / 2002$ & 5 & 120 & 122 & 25 \\
\hline 204-AT-090 & 27 & -64 & $8 / 26 / 2002$ & $9 / 2 / 2002$ & 7 & 120 & 123 & 17 \\
\hline 204-AT-103 & 31 & -50 & $8 / 26 / 2002$ & $10 / 3 / 2002$ & 38 & 120 & 124 & 3 \\
\hline 204-AT-127 & 39 & -14 & $8 / 26 / 2002$ & $9 / 5 / 2002$ & 10 & 120 & 126 & 12 \\
\hline 204-AT-148 & 45 & -25 & $8 / 26 / 2002$ & $9 / 2 / 2002$ & 7 & 120 & 129 & 18 \\
\hline 204-AT-152 & 46 & 28 & $8 / 26 / 2002$ & 9/9/2002 & 14 & 120 & 129 & 9 \\
\hline 204-AT-157 & 48 & 150 & $8 / 26 / 2002$ & $9 / 11 / 2002$ & 16 & 120 & 130 & 8 \\
\hline 204-AT-168 & 51 & 115 & $8 / 26 / 2002$ & $9 / 23 / 2002$ & 28 & 120 & 131 & 5 \\
\hline 205-AT-051 & 16 & -60 & $8 / 26 / 2002$ & $9 / 1 / 2002$ & 6 & 120 & 121 & 20 \\
\hline 205-AT-054 & 16 & -65 & $8 / 26 / 2002$ & $9 / 2 / 2002$ & 7 & 120 & 122 & 17 \\
\hline 205-AT-057 & 17 & -280 & $8 / 26 / 2002$ & $9 / 3 / 2002$ & 8 & 120 & 122 & 15 \\
\hline 205-AT-060 & 18 & -200 & $8 / 26 / 2002$ & $9 / 3 / 2002$ & 8 & 120 & 122 & 15 \\
\hline 205-AT-096 & 29 & -190 & $8 / 26 / 2002$ & $9 / 7 / 2002$ & 12 & 120 & 124 & 10 \\
\hline 205-AT-105 & 32 & -370 & $8 / 26 / 2002$ & $9 / 14 / 2002$ & 19 & 120 & 125 & 7 \\
\hline 205-AT-125 & 38 & -330 & $8 / 26 / 2002$ & $9 / 2 / 2002$ & 7 & 120 & 126 & 18 \\
\hline 205-AT-128 & 39 & -350 & $8 / 26 / 2002$ & $9 / 2 / 2002$ & 7 & 120 & 127 & 18 \\
\hline 205-AT-132 & 40 & -190 & $8 / 26 / 2002$ & $9 / 3 / 2002$ & 8 & 120 & 127 & 16 \\
\hline 205-AT-146 & 45 & -75 & $8 / 26 / 2002$ & $9 / 29 / 2002$ & 34 & 120 & 128 & 4 \\
\hline 207-AT-129 & 39 & -250 & $6 / 18 / 2002^{\mathrm{a}}$ & $7 / 4 / 2002$ & 16 & 129 & 135 & 8 \\
\hline 207-AT-134 & 41 & -230 & $6 / 18 / 2002$ & $7 / 3 / 2002$ & 15 & 129 & 135 & 9 \\
\hline 207-AT-145 & 44 & -130 & $6 / 18 / 2002$ & $7 / 24 / 2002$ & 36 & 129 & 136 & 4 \\
\hline 215-AT-078 & 24 & -40 & $8 / 26 / 2002$ & $8 / 30 / 2002$ & 4 & 137 & 140 & 36 \\
\hline 215-AT-142 & 43 & -15 & $8 / 26 / 2002$ & $9 / 8 / 2002$ & 13 & 137 & 144 & 11 \\
\hline 215-AT-149 & 45 & -100 & $8 / 26 / 2002$ & $9 / 13 / 2002$ & 18 & 137 & 145 & 8 \\
\hline 215-AT-190 & 58 & -1 & $8 / 26 / 2002$ & $9 / 23 / 2002$ & 28 & 137 & 149 & 5 \\
\hline 215-AT-286 & 87 & 85 & $8 / 26 / 2002$ & $10 / 31 / 2002$ & 66 & 137 & 163 & 2 \\
\hline
\end{tabular}




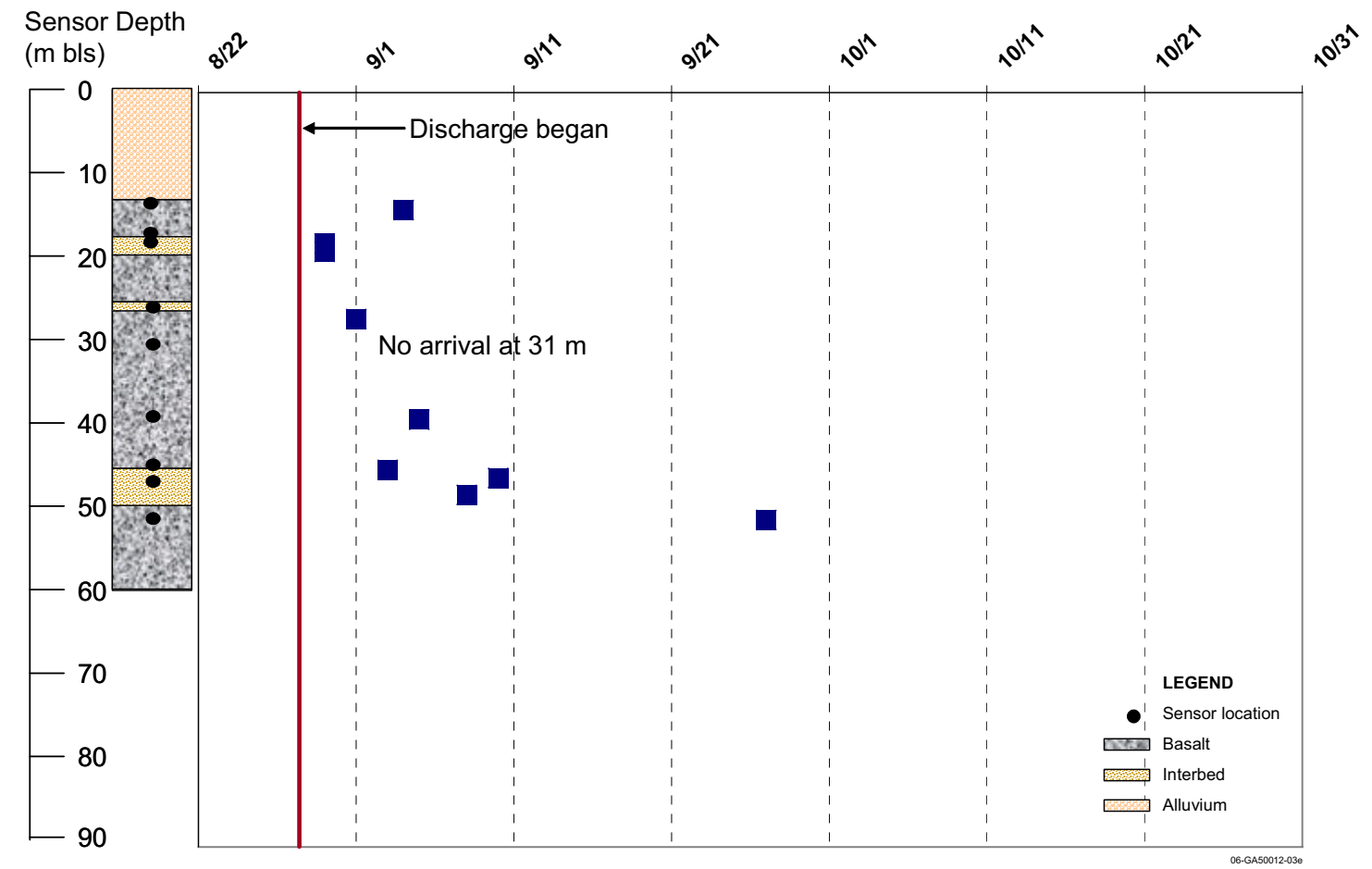

Figure 9. Water arrival sequence beneath the VZRP percolation ponds for Borehole ICPP-SCI-V-204, based on tensiometer data collected from July 1, 2002 through October 31, 2002. This is an example of preferential flow where water arrival occurred nonsequentially with depth. 


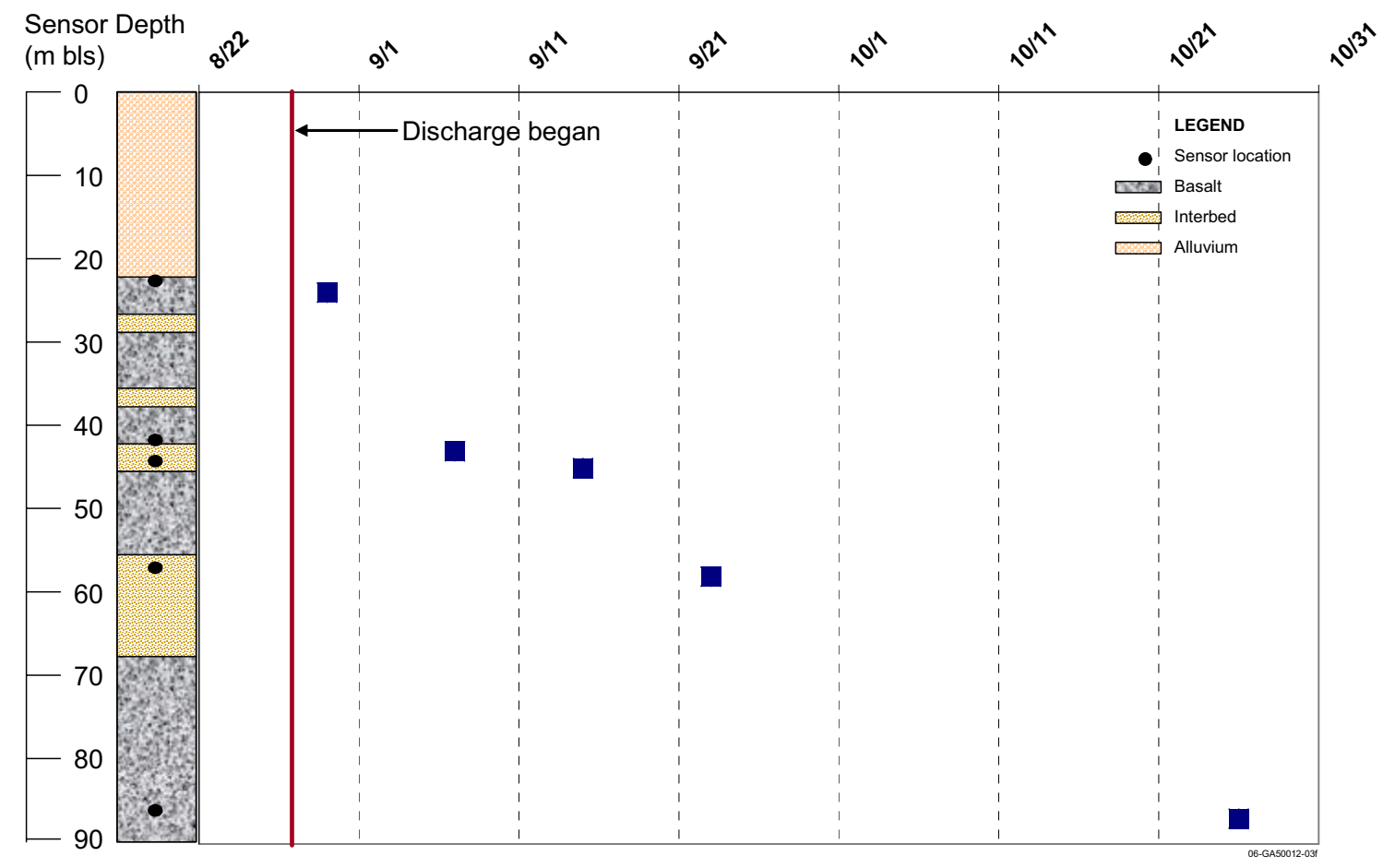

Figure 10. Water arrival sequence beneath the VZRP percolation ponds for Borehole ICPP-SCI-V-215, based on tensiometer data collected from July 1, 2002 through October 31, 2002. This is an example of diffuse flow where water arrives sequentially with depth. This was the only instrumented borehole that exhibited this type of water arrival. 


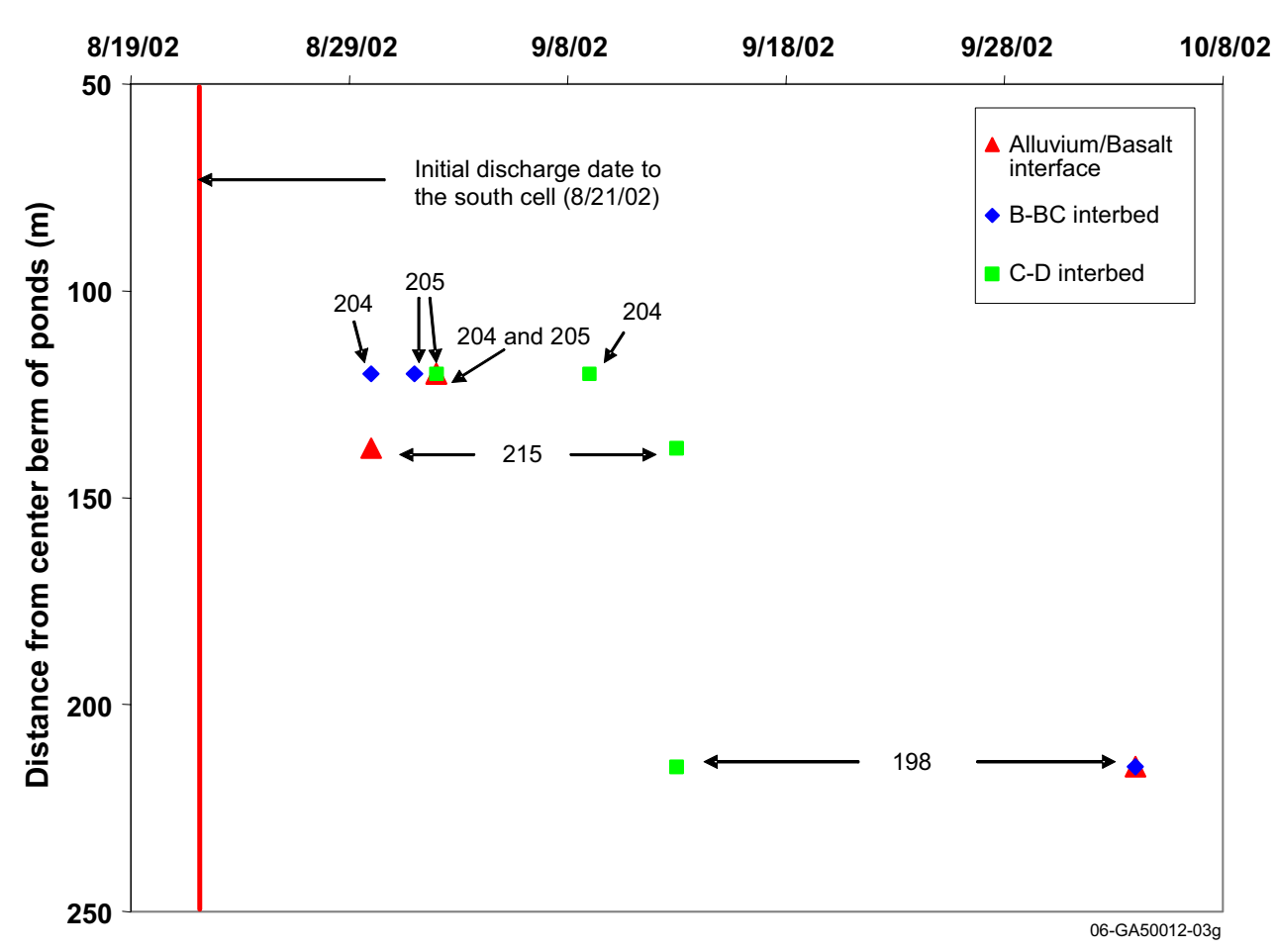

Figure 11. Grouped lithology initial water arrival dates as a function of lateral distance from the center of the berm between the ponds for the alluvium/basalt interface, the B-BC interbed, and the C-D interbed for Wells ICPP-SCI-V-198, ICPP-SCI-V-204, ICPP-SCI-V-205, and ICPP-SCI-V-215.

\subsection{Extent of Lateral Transport}

The perched water thickness increased near the Big Lost River channel, $860 \mathrm{~m}$ from the New Percolation Ponds, in Well ICPP-SCI-V-189 at $31 \mathrm{~m}$ bls in early September 2002, shortly after initial discharge to the ponds began (Figure 12). Rapid infiltration to this well was considered an anomaly (flow velocities for this well were not presented in Table 2) and instrument malfunction was considered a possibility. For this reason, the pressure transducer at this depth was pulled for calibration in October 2002 and temporarily replaced with an alternate transducer for one month until calibration was completed. The observed pressure did not change significantly between the original transducer, the temporary transducer, nor the re-calibrated transducer. This suggests that the original and alternate transducers were functioning properly. Video logs recorded before instruments were placed in the well show standing water in the borehole at approximately $33 \mathrm{~m}$ bls, confirming the presence of perched water at this depth before discharge began at the New Percolation Ponds. Recharge to the well was observed during tracer study sampling in June 2003. The pressure transducer assembly was pulled and hung in the sensor access tube at approximately $30 \mathrm{~cm}$ to allow water to enter the tube for sampling of tracer concentrations (Figure 12). The access tube was purged dry during water sampling but water refilled the access tube within 1 to 2 days after each sampling purge, returning to pre-purge water levels.

Water samples collected during the June 2003 sampling and subsequent Big Lost River infiltration sampling (June 2005) show chloride concentrations of approximately $100 \mathrm{ppm}$, which are an order of magnitude higher than pre-operation concentrations analyzed from nearby lysimeters (Figure 13). 


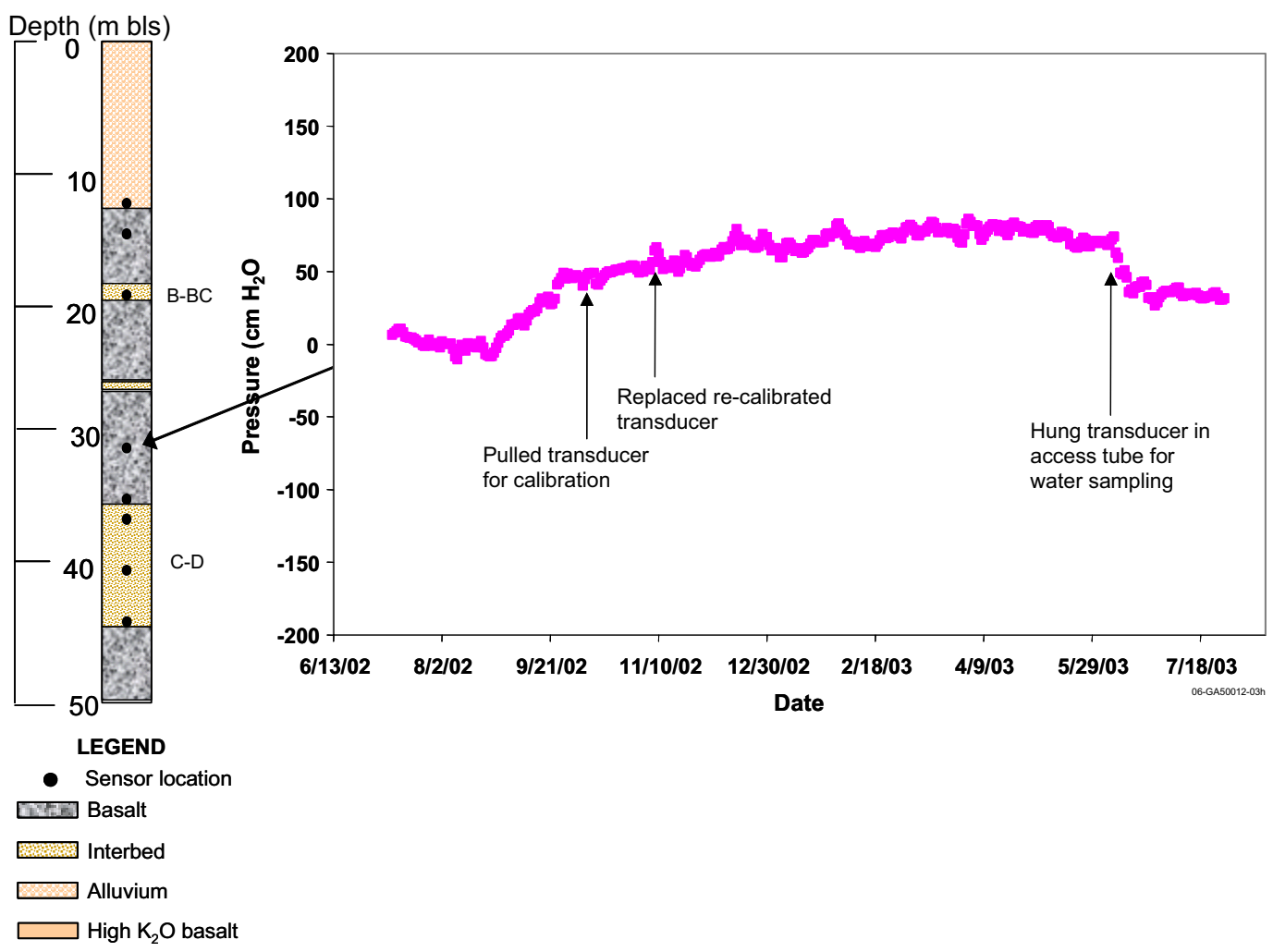

Figure 12. Well ICPP-SCI-V-189 advanced tensiometer readings at $31 \mathrm{~m}$ bls. Pressure began to increase in early September 2002 and reached a steady value of approximately $70 \mathrm{~cm}$ positive pressure in March 2003. 


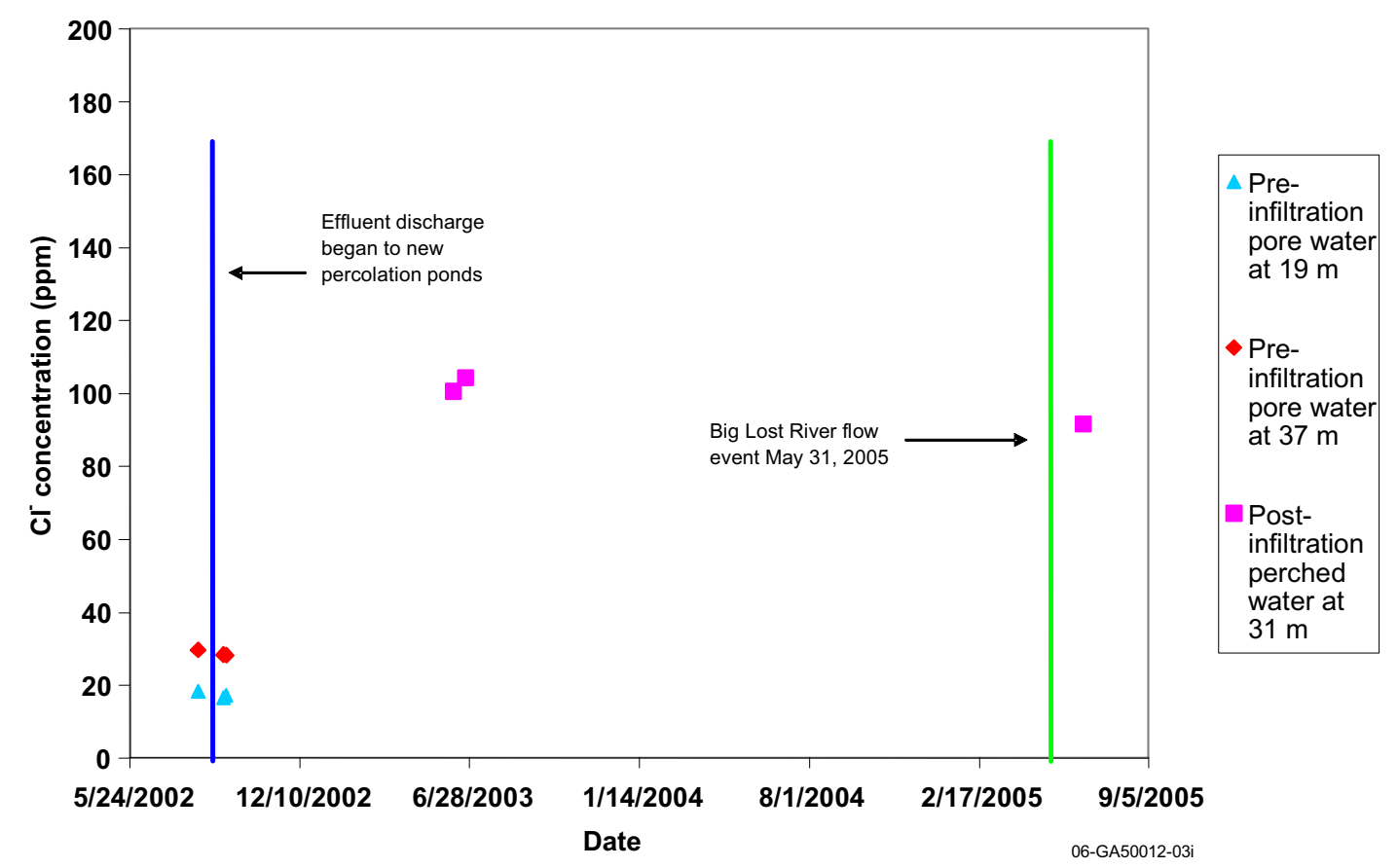

Figure 13. Chloride concentrations in pore water and perched water at approximately $30 \mathrm{~m}$ depth north of the Big Lost River. Note the decrease in chloride concentration after the Big Lost River flow event in June 2005, most likely due to dilution from infiltrating Big Lost River water.

\subsubsection{Steady State Perched Water Conditions}

Figure 14 shows regions of perched water in the vadose zone beneath the New Percolation Ponds after one month of high-volume continuous discharge to the south cell. Nearly all depths were saturated in boreholes adjacent to the ponds, with the exception of a few shallow locations and thick basalt layers. Well ICPP-SCI-V-198 was saturated from 34 to $43 \mathrm{~m}$ bls, even in the basalt layers, but was unsaturated at all locations shallower than $34 \mathrm{~m}$ bls. Well ICPP-SCI-V-215 was saturated at all sensor locations from 24 to $87 \mathrm{~m}$ bls; however, water arrival had not been observed in sensors located in thick basalt at 102 and $147 \mathrm{~m}$ bls. The pre-operation perched water zone identified at $87 \mathrm{~m}$ bls southeast of the ponds (in Well ICPP-SCI-V-215) increased gradually in thickness from October 2002 through July 2003 (Figure 15). The perched water zone identified north of the ponds at approximately $45 \mathrm{~m}$ bls (Wells ICPP-SCI-V-204, ICPP-SCI-V-198, ICPP-SCI-V-214, ICPP-SCI-V-195, ICPP-SCI-V-214, and ICPP-SCI-V-189) increased significantly in thickness in wells near the ponds (ICPP-SCI-V-204 and ICPP-SCI-V-198) and in Well ICPP-SCI-V-189, but did not increase midway between the ponds and the Big Lost River in Wells ICPP-SCI-V-195 and ICPP-SCI-V-214.

Figure 15 shows the formation of new perched zones, observed after 6 months of discharge to the percolation ponds. New perched water formed at most interbed/basalt interfaces monitored around the perimeter of the ponds (extending $200 \mathrm{~m}$ laterally to the north and vertically to a depth of $76 \mathrm{~m} \mathrm{bls}$ ). Water-level monitoring Wells ICPP-MON-V-210 and ICPP-MON-V-211 south of the ponds had 4 and $5 \mathrm{~m}$, respectively, of water pressure after 6 months of continuous discharge to the south cell. Wells ICPP-MON-V-202 and ICPP-MON-V-200 on the north end of the ponds had 2 and $5 \mathrm{~m}$ of water pressure, respectively, after 6 months of discharge to the south cell. Well ICPP-MON-V-212 had $4 \mathrm{~m}$ of water pressure, and Well ICPP-MON-V-197 had 3 m of water pressure after 6 months of discharge. All monitoring locations shown in Figure 15 were unsaturated before high volume continuous discharge to the New Percolation Ponds began. 


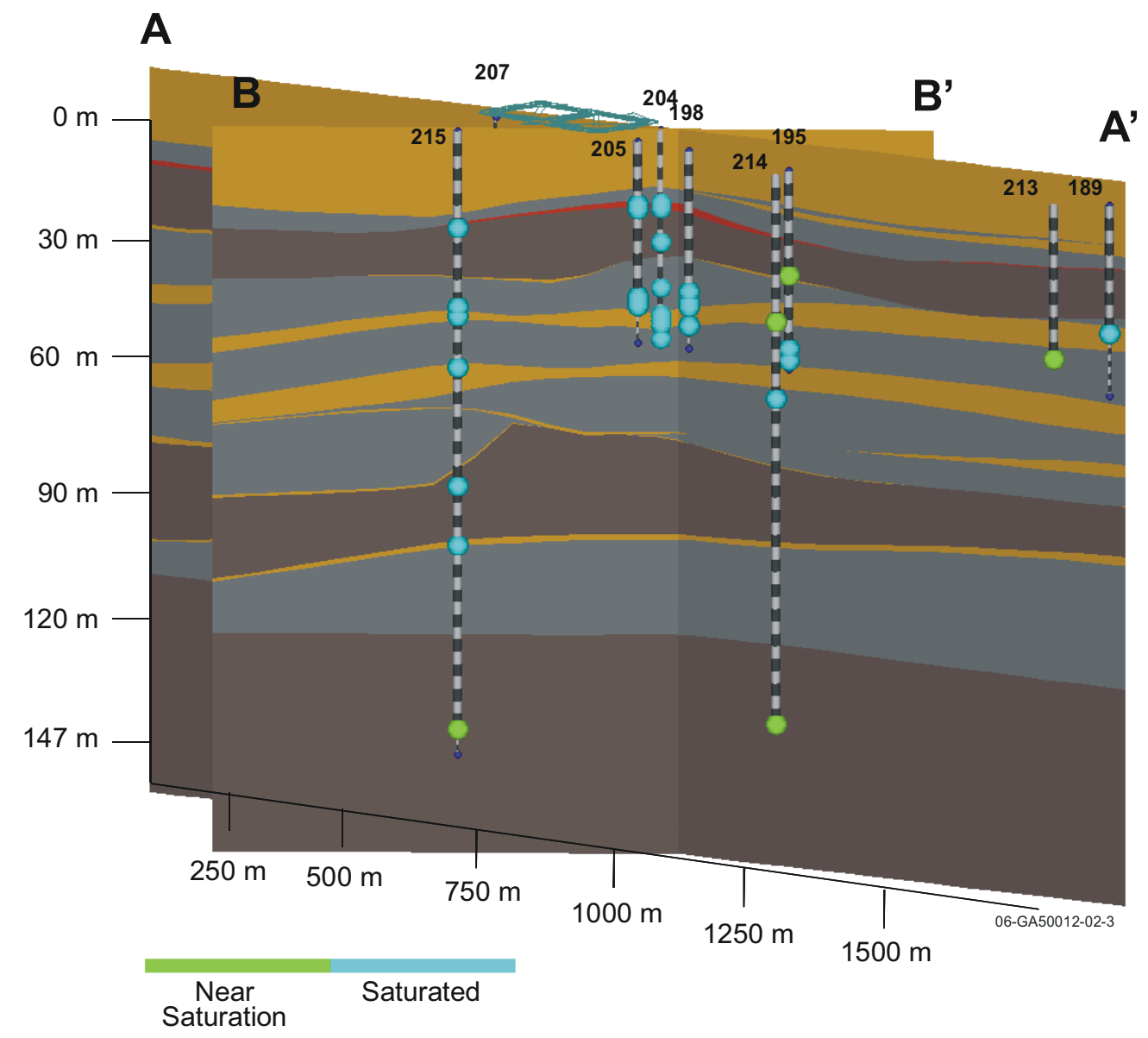

Figure 14. Hydraulic conditions after one month of continuous discharge to the south cell at the New Percolation Ponds (data taken October 31, 2002). Blue bulbs represent perched water conditions, green bulbs represent near saturation ( $\sim 0 \mathrm{~cm}$ hydraulic pressure head). 


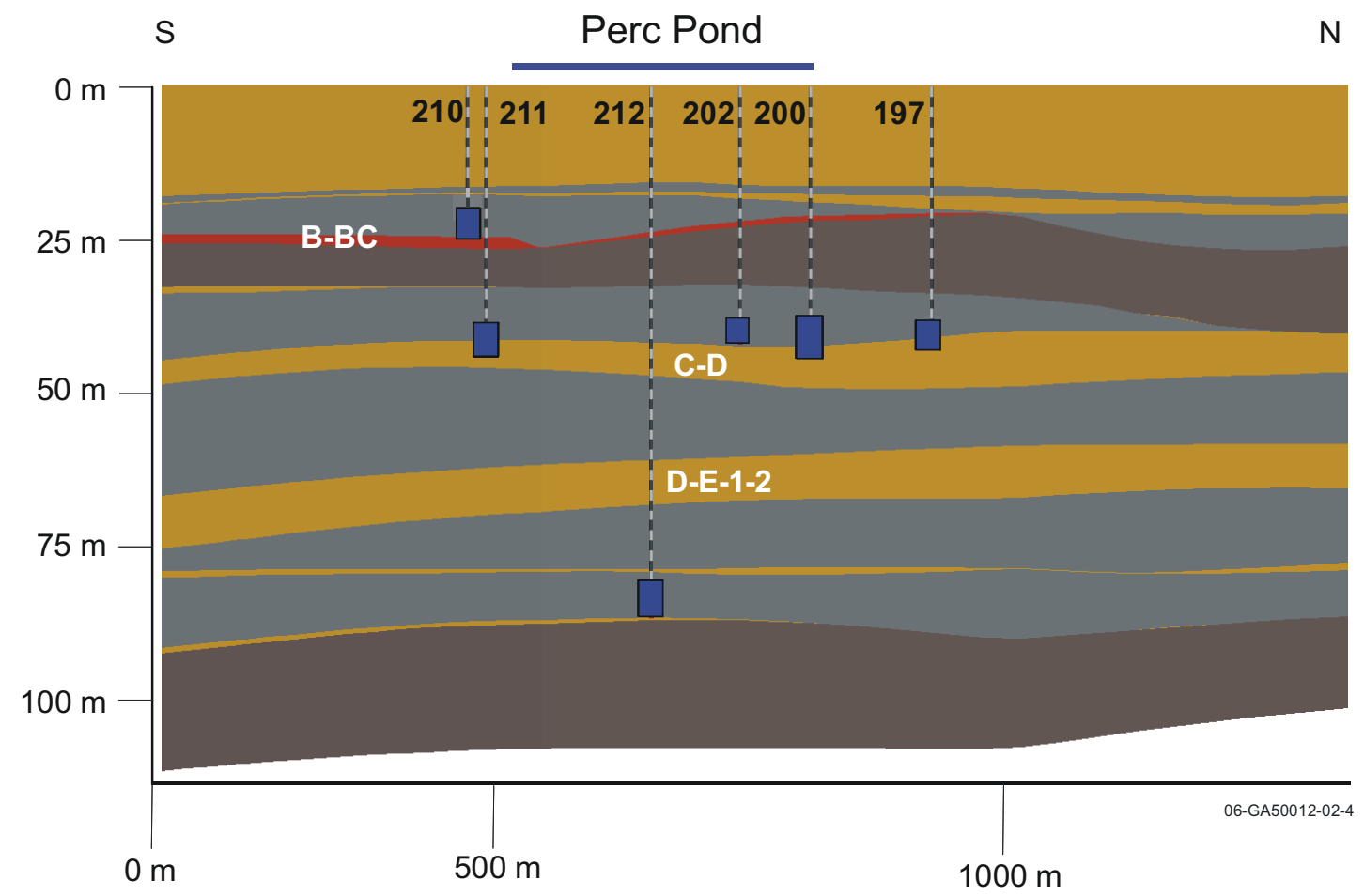

Figure 15. Perched water thickness measured in vadose zone monitoring wells at the VZRP in March 2003. All these wells were dry before pond discharge began.

\subsection{Repeatability Tests}

Subsurface monitoring in 2002 through 2004 showed that both the shallow (less than $20 \mathrm{~m}$ deep) and deep tensiometers and water-level sensors responded to periodic switches in discharge location from the south cell to the north cell of the ponds. The response to discharge location changes indicates a high degree of spatial variability in geohydrologic properties controlling infiltration pathways. To quantify the dependence of infiltration pathways on surface discharge location, we conducted controlled discharge switches from October 14, 2004 through December 14, 2004, alternating discharge every 2 weeks between pond cells, while maintaining a relatively uniform effluent discharge rate.

An example of the hydraulic response to discharge repeatability is shown in Figure 16. These advanced tensiometer measurements were made at various depths in Well ICPP-SCI-V-205, located on the north side of the ponds approximately $130 \mathrm{~m}$ from the center berm, during the controlled switches. Shallow sensors located at the alluvium/basalt interface $(15 \mathrm{~m}$ depth) show rapid response to discharge location switches, while deeper sensors located in the C-D interbed (40 $\mathrm{m}$ depth) showed a delayed response. Regardless of the response time, all sensors in Well ICPP-SCI-V-205 showed a reduction in perched water thickness (represented as $\mathrm{cm}$ pressure head) after discharge was switched to the south cell, followed by an increase in perched water thickness during discharge to the north cell. Wells on the south and northwest sides of the ponds showed similar behavior, with sensors on the south side of the ponds showing greater perched water thickness during south cell discharge and lower perched water thickness during north cell discharge. 
Observed hydraulic responses during the controlled discharge switches validate the dependence of perched water conditions and transport pathways on surface discharge location and suggest that the response is repeatable under similar boundary and initial conditions. By quantifying hydraulic response as a function of discharge location, we can determine the impact of changing boundary and initial conditions (i.e., water chemistry, water content, discharge rate, etc.) on subsurface infiltration and solute transport.

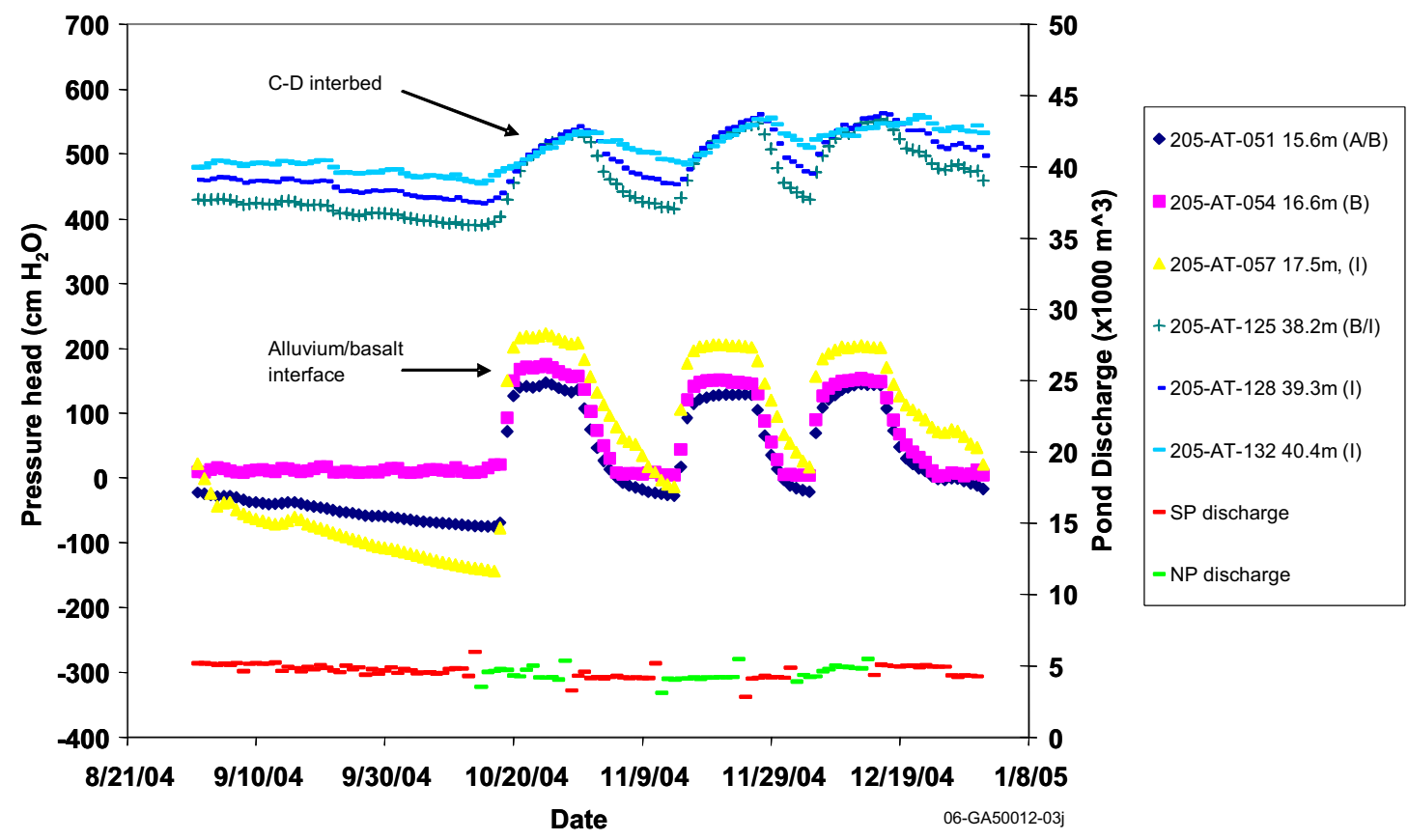

Figure 16. Example of hydraulic response to changes in discharge location during controlled effluent discharge switches between the north and south cells of the percolation ponds at the VZRP from October 2004 through December 2004.

\section{CONCLUSIONS}

Water transport through perched water zones and fast pathways is of particular concern in predicting contaminant transport and in long-term stewardship of contaminated vadose zones. Formation of perched water increases hydraulic conductivity, reducing chemical residence time and sorption, consequently increasing the potential for spreading contaminants great distances from source areas. Fracture networks within rock layers are difficult to characterize using traditional methods and are often neglected in transport predictions. Hence, current vadose zone transport models fail to capture the potential for rapid transport through fractured rock. Long-term stewardship requires a better understanding of mechanisms contributing to the formation and longevity of perched water zones, as well as transport within these zones, and a means to characterize and incorporate fracture networks into vadose zone transport models.

Historically, INL has adopted diffuse-flow conceptual models for contaminant transport in the vadose zone, and risk management decisions have been based on the assumption of diffuse transport. Recent investigations at INL (Dunnivant, Newman et al. 1998; Faybishenko, Doughty et al. 2000; Nimmo, Perkins et al. 2002; Hull and Bishop 2003) suggest that water may instead be moving along more preferential flow paths. Hydrological data collected at the VZRP support these findings and show that 
preferential flow conceptual models are the most appropriate for describing flow in the vadose zone in this region of the INL.

The current monitoring structure at the VZRP is providing researchers with valuable information to better understand the complexity of transport in heterogeneous vadose zones. However, additional instrumentation and research focusing on (a) individual pathways under controlled boundary conditions and (b) the formation, longevity, and extent of perched water zones would contribute greatly to improving the conceptual model for contaminant transport in complex, heterogeneous vadose zones.

\section{REFERENCES}

Champion, D. E. and T. C. Herman (2003). Paleomagnetism of Basaltic Lava Flows in Boreholes ICPP-213, ICPP-214, ICPP-215, and USGS-128 near the New Percolation Ponds, Idaho Nuclear Technology and Engineering Center (INTEC). Idaho Falls, Idaho, U.S. Geological Survey.

Dunnivant, F. M., M. E. Newman, et al. (1998). "Water and Radioactive Tracer Flow in a Heterogeneous Field-Scale System." Ground Water 36(6): 949-958.

Faybishenko, B., C. Doughty, et al. (2000). "Conceptual Model of the Geometry and Physics of Water Flow in a Fractured Basalt Vadose Zone." Water Resources Research 36(12): 3499-3520.

Hull, L. C. and C. W. Bishop (2003). Fate of Magnesium Chloride Brine Applied to Unpaved Roads to Suppress Dust at the INEEL Subsurface Disposal Area. Idaho Falls, ID, Idaho National Engineering and Environmental Laboratory, Bechtel BWXT, Idaho.

Nimmo, J. R., K. S. Perkins, et al. (2002). "Kilometer-Scale Rapid Transport of Naphthalene Sulfonate Tracer in the Unsaturated Zone at the Idaho National Engineering and Environmental Laboratory." Vadose Zone Journal 1: 89-101.

Winfield, K. A. (2003). Measurement of Unsaturated Hydraulic Conductivity Functions, Saturated Hydraulic Conductivity, Particle-Size Distribution, Bulk Density, Porosity, and Specific Surface Area for the Vadose Zone Research Park Samples, Idaho National Environmental and Engineering Laboratory (INEEL). Menlo Park, CA, U. S. Geological Survey: 90. 